\title{
Mare nostrum, mare liberum, mare sit aeternum : duurzaam gebruik van de oceanische ruimte
}

Citation for published version (APA):

Stel, J. H. (2002). Mare nostrum, mare liberum, mare sit aeternum : duurzaam gebruik van de oceanische ruimte. Maastricht University. https://doi.org/10.26481/spe.20021108js

Document status and date:

Published: 08/11/2002

DOI:

10.26481/spe.20021108js

Document Version:

Publisher's PDF, also known as Version of record

\section{Please check the document version of this publication:}

- A submitted manuscript is the version of the article upon submission and before peer-review. There can be important differences between the submitted version and the official published version of record.

People interested in the research are advised to contact the author for the final version of the publication, or visit the DOI to the publisher's website.

- The final author version and the galley proof are versions of the publication after peer review.

- The final published version features the final layout of the paper including the volume, issue and page numbers.

Link to publication

\footnotetext{
General rights rights.

- You may freely distribute the URL identifying the publication in the public portal. please follow below link for the End User Agreement:

www.umlib.nl/taverne-license

Take down policy

If you believe that this document breaches copyright please contact us at:

repository@maastrichtuniversity.nl

providing details and we will investigate your claim.
}

Copyright and moral rights for the publications made accessible in the public portal are retained by the authors and/or other copyright owners and it is a condition of accessing publications that users recognise and abide by the legal requirements associated with these

- Users may download and print one copy of any publication from the public portal for the purpose of private study or research.

- You may not further distribute the material or use it for any profit-making activity or commercial gain

If the publication is distributed under the terms of Article $25 \mathrm{fa}$ of the Dutch Copyright Act, indicated by the "Taverne" license above, 
Mare Nostrum - Mare Liberum - Mare sit Aeternum Duurzaam gebruik van de oceanische ruimte 


\section{Colofon!}

(0) Jan H, Stel, Marastricht, 2002

Easisontwerp en realisatie: Unigraphic, Universiteit Maastricht

Whutratie amslag: Bekoringen wan Sint-Antoniws, Jeroen Bosch, 16 die eew

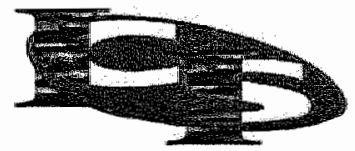

International Centre for Integrative studies (ICIS)

Alle rechten voorbehouden. Niets wit deze uitgave mag worden vervelvoudigd, opgeslagen in een geautomatiseerd gegevensbestand of opembar gemakt, zonder woorafgaande schriftelike toestemming wan de aute ur of uitgever. 


\section{Mare Nostrum - Mare Liberum - Mare sit Aeternum Duurzaam gebruik van de oceanische ruimte}

Rede

Uitgesproken bij de aanvaarding van het ambt van bijzonder hoogleraar Oceanische Ruimte en Menselijke Activiteit aan de Universiteit Maastricht op 08-11-2002

door

Dr. Jan H. Stel 
De zee is geen landschap. Het is een ervaring van de eeuwigheid, van leegte en dood: een metafysische droom.

Thomas Mann, 1875-1955

Hierbij wil ik Kees Wiese, René Malherbe, Magda van Nispen en Derk Loorbach bedanken voor de ondersteuning bij het totstandkomen van de gedrukte versie en de presentatie van mijn rede. 


\section{Mare Nostrum - Mare Liberum - Mare sit Aeternum Duurzaam gebruik van de oceanische ruimte}

Mijnheer de Rector Magnificus,

Dames en heren,

De verlammende angst die de zeevaarders beving zodra zij de kust uit het oog verloren, de angst voor het onbekende waarin zij schepen verzwelgende octopussen, monsterlijke zeeslangen, duivelse draaikolken en helse sirenen vermoedden, waarin zij zelfs vreesden van de aarde af te zullen vallen. Die angst was het grootste probleem voor Hendrik de Zeevaarder toen hij in het vijftiende eeuwse Portugal zijn "Apolloproject" uitvoerde. Hij bleef zelf veilig aan land, maar stuurde zijn doodsbange ontdekkingsreizigers in slechts twintig meter lange karvelen - het eerste speciaal voor de oceaanvaart ontworpen schip in Europa - steeds verder naar het zuiden, de wereldzee op.

Neil Armstrong en Edwin Aldrin wisten in juli 1969 exact waar zij heen gingen: de maan, duidelijk zichtbaar aan het firmament. Gedurende de gehele reis stonden zij in contact met de aarde. Sterker nog: circa 600 miljoen mensen - meer dan de wereldbevolking in de tijd van Hendrik de Zeevaarder [1] - volgden op 21 jull op de tv de eerste stappen van Armstrong op de maan.

De Portugese kapiteins en hun bemanningen verkeerden in een geheel andere situatie. Zodra het land uit zicht was, waren ze - ondanks be- 
langrijke innowaties die het navigeren op zee drastisch hadden verbeterd - op zichzelf aangewezen, overgeleverd aan een gevaarlijke zee vol verrassingen. Zij gingen een volstrekt onzekere toekomst tegemoet, warin de duur en het doel van de reis in feite volstrekt onduidelijk waren. Ook zonder de acute bedreiging van de zee was het leven aan boord van de schepen erbarmelijk. Velen keerden dan ook niet terug.

In de vijftiende eeuw had men slechts interesse voor het bevaarbare deel van de zee en dus vooral voor de kust. Pas aan het eind van de twintigste eeuw ging de 2400 jaar oude voorspelling van Socrates in vervulling. Wij zouden pas iets begrijpen van de wereld waarin wij leven, als wij in staat zouden zijn boven de aarde uit. te stijgen. Van de maan af werd inderdaad duidelijk dat wij leven op een schitterende blauwe parel die we per vergissing aarde hebben genoemd. De aarde, het tehuis van ruim zes millard mensen en miljarden andere organismen, is een kwetsbaar systeem waarin de oceanische ruimte onder meer een belangrijke, regulerende rol speelt.

De uitgestrektheid van de oceaan heeft de mens altijd vervuld met het besef van oneindigheid. In tegenstelling tot het land, waar perioden van schaarste nooit ongewoon waren, leken de rijkdommen van de oceaan onuitputtelijk. Het gebruik van de oceaan was eeuwenlang gebaseerd op de veronderstelling, dat de verschillende manieren waarop de mens van de zee profiteerde, naast elkaar konden bestaan. Er bestonden dan ook nauwelijks regels voor het gebruik ervan. De oceaan was een vrij toegankelijk domein. 
Van oceanografie noar oceanische ruimte

Toen wij een kleine twintig jaar geleden de Tweede Snellius Expeditie in de Bilderdijk kamer van de Academie planden, gingen we uit van cruises van gemiddeld vier weken. Ook nu is dat nog een normale planningseenheid in het oceanografisch onderzoek. In de "science mo$\mathrm{de}^{3 x}$ verricht een schip gedurende vier weken allerlei onderzoek en neemt de gegevens voor verder onderzoek mee naar het laboratorium. De Indonesisch-Nederlandse Tweede Snellius Expeditie - de omvangrijkste naoorlogse expeditie uit de geschiedenis van de Nederlandse oceanografie - duurde zestien maanden. Voor de logistieke uitvoering werd een beroep gedaan op de kennis van de marines van beide landen. Dit is in de oceanografie in het geheel niet ongebruikelijk. In de achttiende en negentiende eeuw waren het steeds marineschepen die op hun reizen een aantal onderzoekers meenamen. Bekende voorbeelden hiervan zijn de reizen van Captain Cook (1768-1779), de reis wan de Beagle (1831-1836) met Darwin aan boord en, om dichter bij huis te

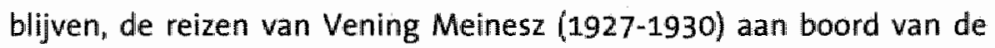
Nederlandse onderzeeër Hr. Ms. 016 in de jaren dertig. Het gevolg van deze reizen was nog al verschillend. De reis van Cook leidde tot de robbenjacht en later de walvisvaart in het subantarctische gebied. Darwin zorgde voor een revolutile in de biologie en Vening Meinesz droeg bij aan een omwenteling in de aardwetenschappen.

Algemeen wordt aangenomen, dat de reis van het Britse korvet Challenger $(1872-1876)$ het begin van het oceanografisch onderzoek markeert. De wetenschappelijke staf bestond uit zes personen, onder wie een illustrator omdat er nog geen digitale camera's waren. De Challenger-reis leidde voor het eerst in de geschiedenis tot een systematische 
beschrijving van de stromingen en temperaturen in de oceaan, van meteorologische waarnemingen boven de oceaan en wan vele, soms bizarre levensvormen in de oceaan [2]. Ruim honderd jaar later werd deze "synoptische" opname van de oceanische ruimte in een moderne versie uitgevoerd binnen het World Ocean Circulation Experiment, dat twaalf jaar duurde. In de nabije toekomst zal dit welkelijks of zelfs dagelijks gebeuren als het Global Ocean Observing System (GOOS) operationeel is.

Het is opvallend, dat het begin van de aceanografie samenvalt met het begin van de Industriële Revolutie. Oceanografisch onderzoek is in hoge mate afhankelijk van ontwilkkelingen in de technologie. Het wergaan van de Titanic op 15 april 1912 leidde tot een versnelde ontwikkeling van de sonar [2]. De beide wereldoorlogen en de Koude Oorlog leidden eveneens tot een enorme "technology push" in de verkenning van de oceanische ruimte. Vooral na de Tweede Wereldoorlog ging het snel. In feite ontwikkelden zich toen twee oceanografische onderzoekslijnen: een militaire en een civiele. De militaire oceanografie was toepassingsgericht en beschikte wegens het strategische belang dat eraan werd toegekend over enorme fondsen. De resultaten waren militair geheim. De uitwisseling van informatie tussen beide werelden was uitermate gering. In feite betaalde de belastingbetaler dikwijls tweemaal voor thet ontwikkelen van min of meer dezelfde kennis over de oceanische ruimte. Wel werden nieuwe onderzoeksinstrumenten soms zeer succesvol toegepast in de civiele oceanografie. Zo leidde de inzet van de Alvin, die oorspronkelijk werd ontwikkeld om een kernbom voor de kust van spanje terug te vinden, tot spectaculaire ontdekkingen in de diepzee. Zonder het Global Positioning Systeem dat in 1959 nodig was voor een betere plaatsbepaling van de Polaris-onderzeeërs met 
behulp van satellieten, zouden veel van de huidige ontwikkelingen in de oceanografie (Argo-floats, gliders) niet mogelijk zijn.

In de afgelopen decennia werd ook duidelijk dat de schaal waarop sommige processen in de oceanische ruimte zich afspelen, de onderzoekcapaciteiten van een enkel land te boven gaan. Internationale samenwerking in programma"s in het kader van het Wereldklimaatprogramma en het Internationale Geosfeer-Biosfeer Programma werd een trend. Dit leidde tot belangrijke doorbraken, als de woorspelbaarheid van het El-Niño-verschijnsel. Hoe lovenswaardig deze onderzoekprogramma's ook zijn, zij zullen pas tot wasdom komen als men in staat is het probleem van het algemene gebrek aan gegevens over de oceaan op te lossen. Hiervoor is GOOS nodig. Helaas bestaat in Nederland op alle niveaus een schrijnend en kortzichtig gebrek aan belangstelling voor dit informatiesysteem voor de oceanische ruimte. Schrijnend, vanwege onze internationale reputatie als innoverende waterbeheerders. Kortzichtig; omdat GOOS ons land veel te bieden heeft als het om het vermarkten van onze kennis en kunde gaat.

Na de val van de Muur werden delen van de milltaire oceanografie toegankelijk voor de civiele oceanografen. Dit leidde tot het beschikbaar komen van gigantische datasets en ongekende mogelijkheden, maar ook tot lagere uitgaven voor de civiele collega's. Het is duidelijk dat een militair-strategisch belang van de oceanische ruimte tot meer fondsen voor onderzoek en monitoring leidt dan het strategische belang van het mariene milieu. 
De oceanische ruimte, een dynamisch systeem

De oceanische ruimte is een wezenlijk en kenmerkend onderdeel van onze planeet. Er vinden intensieve interacties op de randen van het systeem plaats. Met de oceaanbodem, waar een deel van het water wordt gerecycled via hydrothermale bronnen en waar een deel van het water in de diepzeebodem verdwijnt. Met de atmosfeer, waar de interacties van invloed zijn op bijwoorbeeld wolkenvorming (algen) en het klimaat, met de kust en met stroomgebieden van rivieren, en aldus met vele menselijke activiteiten.

De watervallen op het land vallen in het niet bij die in de oceanische ruimte. In de Straat van Denemarken valt maar liefst vijf miljoen kubieke meter water per seconde 3500 meter omlaag! De rivieren van de zee, zoals de Golfstroom en de Koroshiwo, verplaatsen zeventig miljoen kubieke meter water per seconde met een snelheid van een kleine tien kilometer per uur. Dat is honderdmaal zoveel als alle rivieren op het land. In de oceanische ruimte stromen immense watermassa's in allerlei richtingen door en over elkaar. De complexiteit van het fysische systeem is te groot om met de huidige computerkracht goed weer te geven.

In de afgelopen 25 jaar hebben we, dankzij miniaturisatie, het gebruik van nieulwe materialen, akoestische technieken, satellieten, computers en laserapparatuur meer dan ooit geleerd over de aard van de oceanische ruimte. Onze kennis staat echter in de schaduw van wat we nog niet weten. De belangrijkste drijfveren van de komende on twikkelingen zijn nieuwsgierigheid, maatschappelijke overwegingen, de milieuproblematiek en de noodzaak tot ontwikkelingssamenwerking. Belangrijke 
prikkels zullen komen van problemen als verwuiling, overbevissing. toenemende bevolkingsdruk in kustgebieden, schadelijke algenbloeien, mariene biodiversiteit, de noodzaak meer voedsel te produceren en het mondiale probleem van de rol van de oceaam in het klimaatsysteem en de stijging van de zeespiegel.

De oceanografie zal meer holistisch, meer interdisciplinair moeten worden en zal meer verantwoording moeten afleggen aan het brede publiek, de samenleving. Om de juiste beslissingen in het oceaanbeleid te nemen moeten we begrijpen hoe de dingen in de oceanische ruimte werken en welke onderlinge verbanden er zijn. Dat vereist hoogwaardige wetenschap en technologie en de steun van individuen en regeringen. Uiteindelijk gaat het om een geïntegreerde visie op onze planeet, waarin de onderlinge verhoudingen tussen zee, atmosfeer en maatschappij samenkomen. Het is echter onjuist alle nadruk te leggen op de belofte van wetenschappelijke vooruitgang en technologische opllossingen voor de problemen in de oceanische ruimte, zonder te erkennen dat die ook weer tot nieuwe problemen leiden. Het gebruilk van verbeterde sonarinstallaties, visnetten, satellietnavigatie en de toegenomen kennis van oceaanstromingen hebben immers bijgedragen aan de uitputting van visbestanden en deze wellicht zelfs mogelijk gemaakt.

\section{Operationele oceanografie}

De enorme betekenis van de oceanische ruimte voor het klimaat is in de afgelopen tien tot twintig jaar steeds duidelijker geworden. Het bestuderen van ingrijpende klimaatveranderingen als gevolg van menselijke en/of door natuurlijke verschijnselen, is slechts mogelijk als de 
Dutraam gebruik val de oceanische puimte

klimaatmodellen in de supercomputers ook worden gevoed met oceanografische informatie. De kwetsbaarheid en gevoeligheid van het oceaanmillieu en het tekortschieten aan kennis werd erkend op de grote conferentie over milieu en ontwikkeling van de Verenigde Naties, die in 1992 in Rio de Janeiro werd gehouden. De daar vastgestelde "Agen-

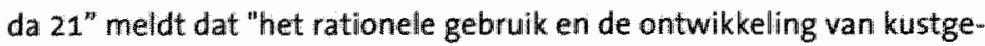
bieden, van alle natuurlijke rijkdommen van de zeeën en het behoud van het mariene milieu, de mogelijkheid vereist de huidige staat van deze systemen te bepalen en toekomstige ontwikkelingen te voorspellen".

GOOS is het antwoord van de mondiale oceanografische gemeenschap op Rio en leidt tot operationele oceanografische dienstverlening. GoOS is te vergelijken met het World Weather Watch (WWW) informatiesysteem van de World Meteorological Organisation (WMO), die overigens al in 1878 ontstond maar pas door de implementatie van de WWW in 1963 tot wasdom kwam. Sinds die tijd wordt het ontstaan van elke tropische storm van minuut tot minuut gevolgd, worden er voorspellingen gedaan over de ontwikkeling ervan en worden vele mensenlevens gered. COOS moet in 2010 operationeel zijn. De exploitatiekosten ervan zijn vergelijkbaar met die van het WWW, ongeveer twee miljard Amerikaanse dollars. Evenveel als vier tripjes naar het Internationale Ruimte Station.

GOOS zal een wereldomspannend netwerk zijn van stations (inclusief de bestaande en nog te lanceren satellieten), intelligente boeien als de Argo-floats enzovoort, om gegevens te verzamelen over de processen die zich in de oceanische ruimte afspelen. Het is dus in feite een mondiaal informatiesysteem dat op een systematische wijze actuele ocea- 
nografische meetgegevens verzamelt en internationaal uitwisselt. Evenals in de meteorologie wordt met behulp van supercomputers en numerieke oceaanmodellen belangrijke informatie gecreëerd. Deze informatie is in te delen in twee categorieën en wel in klimaatvoorspellingen en een reeks van oceanografische producten en diensten voor de duurzame exploitatie van de Exclusieve Economische Zone (EEZ).

Het zijn vooral de landen met een geavanceerde oceanografische infrastructuur - meestal de rijke westerse landen - die profiteren van de nieuwe inzichten in de processen in de oceanische ruimte. Deze landen beschikken immers behalve over de technische kennis ook over de financiële mogelijkheden de voorraden in de oceanische ruirnte te exploiteren. Er is solidariteit nodig om GoOS op een politiek en maatschappelijk verantwoorde wijze te implementeren. Het mondiale aspect betekent zonder meer dat ontwikkelingslanden door kennisoverdracht en partnerships in staat moeten worden gesteld aan GOOS bij te dragen en ervan te profiteren.

Oceaan als transportweg

Het gebruik van schepen in welke vorm dan ook, gaat op zijn minst 30.000 jaar terug. Dat blijkt uit opgravingen op de Bismarck Eilanden in de Stille Oceaan bij Papua Nieuw-Guinea. Het bleek dat deze eilanden toen al bewoond waren. De oudste beschrijving van handel over zee dateert van ongeveer 7250 voor onze jaartelling. Het betreft de handel tussen het Griekse vasteland en het eiland Milos in de Egeïsche Zee.

Zo'n 4000 jaar voor Christus legden de Egyptenaren zich ook toe op de ontwikkeling van de scheepsbouw en de navigatie, waardoor met na- 
me zeereizen in het Middellandse Zeegebied, maar ook naar het Harappa-gebied in India, mogelijk werden. Later zijn het de Feniciërs (die in de zesde eeuw voor Christus rondom Afrika zeilden), de Grieken, de Romeinen en vervolgens de stadstaten Genua en Venetië die de rol van de belangrijkste zeevarende natie in het Middellandse Zeegebied overnemen.

In de Indische oceaan waren het de Arabieren, die de handel van Mombasa in Kenia tot Kanton in China overheersten. De maritieme ontwikkelingen in de Stille Oceaan ontrokken zich tot in de zestiende eeuw aan de Europese waarnemingen. We wisten niets van de migratie in de Stille Oceaan waarbij de Polynesiërs een groot deel van de eilanden koloniseerden. De kennis van de Arabieren en de Chinezen overtrof toen die van de Europeanen in hoge mate. Zo kende men het kompas, waren de schepen van de Chinese ontdekkingsreiziger admiraal Zheng He voorzien van kanonnen en beschikte men over kaarten van Afrika, waarop de driehoekige vorm van het continent was aangegeven [3].

In een reeks van zeven expedities bezocht Zheng He tussen 1405 en 1433 India, de Perzische Golf, de oostkust van Afrika (Malindi) en vermoedelijk ook het Caribische Gebied en de Golf van Californië [4]. De vloten van Zheng He waren indrukwekkend en overtroffen de latere Europese vloten vam ontdekkingsreizigers tot in de huidige tijd. Aan Zheng He's expedities namen gemiddeld 30.000 mensen alan boord van ongeveer 300 schepen deel. De vloten van Zheng He bestonden uit een mix van schepen, walarvan sommige groter dan 3000 ton met een leng. te van 120 meter en een breedte van ongeveer vijftig meter. 


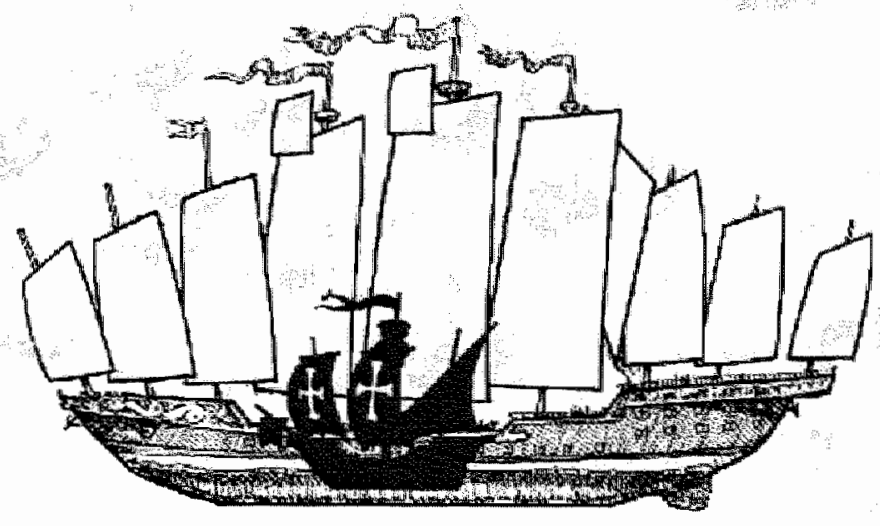

Zheng He's vlaggenschip (1420) en de St. Maria van Columbus (1492): een wereld van verschil.

De schepen vervoerden een zeer gevarieerde bemanning van artsen, accountants, tolken, geleerden, geestelijken, astrologen, handelaren en kunstenaars. Een verandering in het Chinese beleid leidde ertoe dat deze exploraties werden gestopt. Hierdoor kregen de Europeanen de kans een wereldmacht te vormen.

In dezelfde tijd stichtte de Portugese Prins. Hendrik de Zeevaarder de eerste multidisciplinaire zeevaartschool ter wereld in de Algarve. De bundeling van kennis leidde tot innovaties die een meer nauwkeurige plaatsbepaling op zee mogelijk maakten en een nieuw scheepsmodel van vijftig ton en een bemanning van twintig mensen, de Portugese karveel. Dit leidde uiteindelijk tot een ongekende expansie van de Portugese handel en invloedssfeer. 
In termen van integrated assessment was de tijd rijp voor een transitie die daadwerkeljik begon aan het einde van de vijftiende eeuw met de ontdekkingsreizen van Christoffel Columbus (1492), Vasco da Giama (1497-1498), Ferdinand Magelhâes (1519-1522) en John Cabot (1497). Een slordige honderd jaar later bereikte deze transitie een nieuwe stabiele fase met onder andere de oprichting van Compagnieën, waarvan de in 1602 opgerichte Nederlandse Verenigde Oost-Indische Compagnie (VOC) het meest treffende voorbeeld is. Deze transitie, die ik de VOC-transitie heb genoemd, betreft in feite de overgang van een op zichzelf gericht Europa met stadstaten en koninkrijken naar een Europa van kolonialisme en imperialisme, mogelijk gemaakt door de stap van kustvaart naar grote vaart.

\section{VOC-transitie}

"Wie de zee beheerst, beheerst de handel"

(Sir Walther Raleigh, zestiende eeuw)

Transities zijh structurele veranderingen van de maatschappij of een maatschappelijk deelsysteem, als gevolg van op elkaar inwerkende en elkaar versterkende technologische, economische, sociaal-culturele, ecologische en institutionele ontwikkelingen. Het zijn processen die zich op de langere termijn - ten minste é̉n generatie (25-50 jalar) - afspelen en waar binnen een aantal fasen zijn te onderscheiden. In felte is een transitie de resultante van ontwikkelingen in verschillende domeinen (sociaal-cultureel, ecologie, economie) waarbij op verschillende nivealus (macro, meso en micro) interacties plaatsvinden. De matschappelijke dynamiek van een transitie kan worden gevisualiseerd door een complex stelsel van radertjes die op elkaar inwerken. Elk radertje heeft zijn eigen dymamiek, van de relatief snel werkende economische tot de relatief trage 
sociaal-culturele en de zeer trage ecologilsche radertjes. $Z$ o nu en dan werker deze maatschappelijke radertjes zodanig op elkaar in dat ze elkaar versterken. Dan ontstaat een hransitie [5].

\section{Voorontwikkeling}

Door de strijd tegen de moslims was Europa eeuwenlang afgesloten wan de innovaties die deze cultuur bracht. Het dagelijkse leven in de Middeleeuwen was saal, evenals het Europese dieet dat nawwelijks groenten, fruit en suiker Kende engeen thee, koffie en chocolade en vrijwel geen vers vlees. De nieuwe smaakmakers, kruiden en specerijen, waren duur. De moeizame handel via de Zijderoute was in handen van de Arabieren in Zuid-Europa en een aantal stadstaten als Genua en Venetië. Slechts via de zee kon men zich losmaken uit deze Arabische wurggreep op Europa. Er brak een tijd van exploratie aaru, op geestelijk, wetenschappelijk en artistiek gebied, die later zou worden aangeduid als de Renaissance, Er ontstond een klimat van vernieuwing die witeindelijk de verkenning van de wereld tot ver buiten het wertrouwde, christelijke Europa mogelïk heeft gemaakt. Een verandering die ook nu nog zijn sporen nalaat.

Het nnovatiecentrum, dat Hendrik de Zeevaarder in 1418 in Sagres in de Algarve van Portugal stichtte, was een van de signalen voor verandering. Op deze eerste, multidisciplinaire zeevaartschool ter wereld bracht hij wiskundigen, cartografen, astronomen, lloodsen, zeeofficieren, studenten en reisbeschrijwers samen om innovaties te bewerkstelligen, die het vinden wan toegangismegen naar Indie via de oceaan mogelijk moesten maken. Innowattes uit die tijd zijn verbeterde kaarten, het kompas, de astrolabus en de kwadrant, die een meer naumkeurge plaatsbepaling op zee mogelijk maakten en aldus de weg over de openoceaan openden.

Een rieuw scheepsmodel van vijftig tory en een bemanning wan twintig mensen, de Portugese karveel (een combinatie van de bestaande, logge wrachtwaarders 
Durzaom gebruik van de oceonische ruimte

met een mast en de Arabische dhow), laidde uiteindeligk tot een ongekende expansie wan de Portugesie handel en invloedssfeer. Vele ontdekkingsreizen waren het gevolg. Zo werd in 1420 Madeira ontdekt, in 1432 de Azoren en vonden er in de periode 1444-2446 een groot aantal reizen plats waarbij de Kaapverdische Eilanden en Sierra Leone werden ontekt. De belangrijkste en meesti bekende reizen zijn echter die van Bartholomeu Diaz die in 1487 Kaap de Goede Hoop ontdekte en Vasco da Gama (1497-1498), die de route naar india vond. Uiteindelijk bleek de Portugese maatschappij niet in staat de nieuwe mogeljikheden van deze exploratie ten volle te benutten. Ini de termen wan het transitie denken kunnen we stellen, dat in de voorontwikkeling op het nicheniveau allerlei innowaties plaatsvonden. De gevestigde orde op mesoniweau werkte vaak belemmerend op de expansiedrift van Hendrik de Zeevaarder, die met steun van thet Hof (macroniveau) zijn plannen wist door te zetten. Het take-off moment wordt gekenmerkt door de al genoemde reeks van ontdekkingsreizen.

\section{Versnellingsfase}

De speurtocht van de Portugezen om een route naar lndië rondom Afrika te vinden, lleidde ook tot pogingen wan andere landen om een nieuwe route te vinden. Zo zeilde Christoffel Columbus in opdracht van de Spaanse koning, naar het westen waar hij in 1492 Amerika ontdekte. Ferdinand Magelhâes (1519 1522) reisde op Spaanse kosten voor het eerst de wereld rond. Geen wan beiden ontdekte een nieuwe weg naar de schatten van Indië. Wel droegen ze bij aan een snel veranderend wereldbeeld. Omdat Spanje en Portugall een strikt monopolie handhatden op de ruidelike oceaaniroutes naar lndiê, zocht men in Engeland Nederland naar een noordelijke route die er wolgens de toenmalige wetenschappelijke inzichten zou moeten zijn. De belangstelling voor een noordelijke doorvaart verminderde echter vrij snel, omdat vele expedities nooit terugkeerden. Aan het einde van de zestiende eeuw herleefde de belangstelling: 
voor een noordoostelijke doorvart. De reizen van willem Barentsz (1594, 1596 1597) zijn daarvan een bekend vaorbeeld.

Aan het eind van de zestiende eeuw vond er op macroniveau een belangrijke verschuiving plaats in de toen heersende, politieke constellatie. spanje begon zijn positie als wereldmacht te verliezen. Opkomende wereldmachten als Engeland en Nederland manifesteerden zich in toenemende mate. Zo versloegen de Engelsen in 1588 de uit 130 schepen bestaande Spaanse Armada en beèindigden hiermee de Spaanse overheersing op zee. Het politiek-maatschappelijke klimaat in Nederland was rijp voor verandering. Men had zich ontworsteld aan de Spaanse overheersing en domineerde de lucratieve haringvisserij. Hierdoor beschikte de private sector over voldoende middelen voor de verkenning van nieuwe zeeroutes.

Toen Antwerpen in 1585 weer in Spaanse handen kwam, was de Nederlandse Republiek een toevluchtsoord van vele kapitaalkrachtige ondernemers, geschoolde ambachtslieden, intellectuelen en kunstenaars. Bovendien beschikte de Nederlandse Republiek op het nicheniveau over voldoende kennis door de verhalen van Dirck Gerritsz en Jan Huygens van Linschoten, die jarenlang in dienst van de Portugezen in Azië hadden gewerkt. Om helemaal op zeker te spelen hadden de Amsterdammers ook nog eens twee spionnen naar Lissabon gestuurd en wel Cornelis en Frederick Houtman. Zij keerden terug met 25 recente zeckaarten wan de beroemde hofcartograaf van Filips 11 , Bartolomeo de Lasso. Rondom de eeurnwisseling heerste er in die Nederlandse Republekek dus een periode van vooruitgang, waarin ondernemingsgeest en wetenschap een belangrijke rol speelden.

Toen Filips ill in 1591 de Nederlanders hun contract voor de winstgevende harm del in specerijen ontnam, besloten zowel de staat als de kooplieden naar nieuwe 
Duurzaam gebruil van de oceanische ruimte

oplossingen - een eigen route naar Aze - te zoeken. Op grond van onder andere de kaiarten van Plancius zochten de verschillende Compagnieën naar een nieuwe noordoosteligke doorvaart en gebrukten zij de al bekende zuidelijke route. De eerste tocht van Comelis Houttman (1595-1597) was - hoewel niet commercieel - een succes en legde de basis woor de eerste "multinational" in de geschiedenis, de Verenigde Oost-Indische Compagnie, die wel onder enige dwang van de overheid ontstond [6]. De VOC kreeg het alleenrecht op de handel in Azie en thet recht haar belangen met militaire middelen te verdedigen [7].

\section{Stabilisatie}

Zowel in Engeland als in Nederland werd in het begin van de zeventiende eeww (respectievelijk 1600 en 1602) een Compagnie opgericht, die ongeveer twee eeuwen lang de handel tussen Europa en Azië beheerste. De Nederlanders leverden nog vele jaren een felle strijd met de Portugezen en duldden geen Engelse schepen in "hun" eilandenrijk dat beschermo werd door een reeks vestingen als Kaapstad en Batavia. Tegen het midden van de zeventiende eeuw beschikte de VOC over ruim 2000 schepen, had men ruilm 30.000 mensen in dienst, werden ontdekkingsreizen uitgevoerd naar Australië en Nieuw-Zeeland [4] en was het concept wan Mare Liberum ingevoend en geaccepteerd. De Engelse Compagnie rïchtte zich noodgedwongen op India (ijzer, lood, tin, katoen, zijde, specerijen en edelstenen), dat ze onder hun bewind brachten. Ten slotte beheersten de Engelsen ook de handel op China en zetten daarmee op den duur de Hollandse rivaal buitenspel. Aldus werd een transitie van een op zichzelf gericht Europa met stadstaten en koninkrijken maar een Europa van kolonialisme en imperialisme, een feit. 


\section{Oceaan en visserij}

Het oudste gebruilk dat de mens van de zee maakte, is de visvangst. Wellicht waren de vissers in een samenleving van jagers en verzamelaars de eerste echte specialisten en stichtten ze de oudste bedrijfstak ter wereld. Zolang de visserij zich beperkte tot vangst vanaf de kust was er weinig aan de hand en leken de voorraden onuitputtelijk. De mogelijkheden van deze bedrijfstak namen flink toe toen men ontdekte dat het snelle bederf van de koopwaar door conserveringstechnieken als drogen en inzouten, kon worden tegengegaan. Met de ontwikkeling van de moderne koel- en conserveringstechnieken en snellere verkeersmiddelen op het land namen de afzetmogelijkheden voor visproducten na de Tweede Wereldoorlog enorm toe. De vissersvloten van de voormalige Sovjet Unie en Japan stroopten de zeeën af naar vis. Overbevissing van met name de gewilde soorten als kabeljauw, schelvis en schol was al snel een feit.

De visserijsector, waarin 36 miljoen mensen werken [8], is al lang een belangrijke economische factor. De belangen zijn zelfs zo groot dat het "beheer" van of beter gezegd "de toegang tot" visserijgebieden tot conflicten leidt. De eerste signalen, dat een voortdurende overbevissing niet alleen tot geringere opbrengsten en kleinere vissen leidt, maar zelfs tot de ineenstorting van een visbestand, stammen uit de veertiger jaren toen de Californische sardinevisserij instortte. Honderd jaar visserij-onderzoek in ICES-verband en decennia technologische ontwikkeling hebben de teloorgang van deze voorraad niet kunnen voorkomen. Ja, mogelijk zelfs juist in de hand gewerkt? 


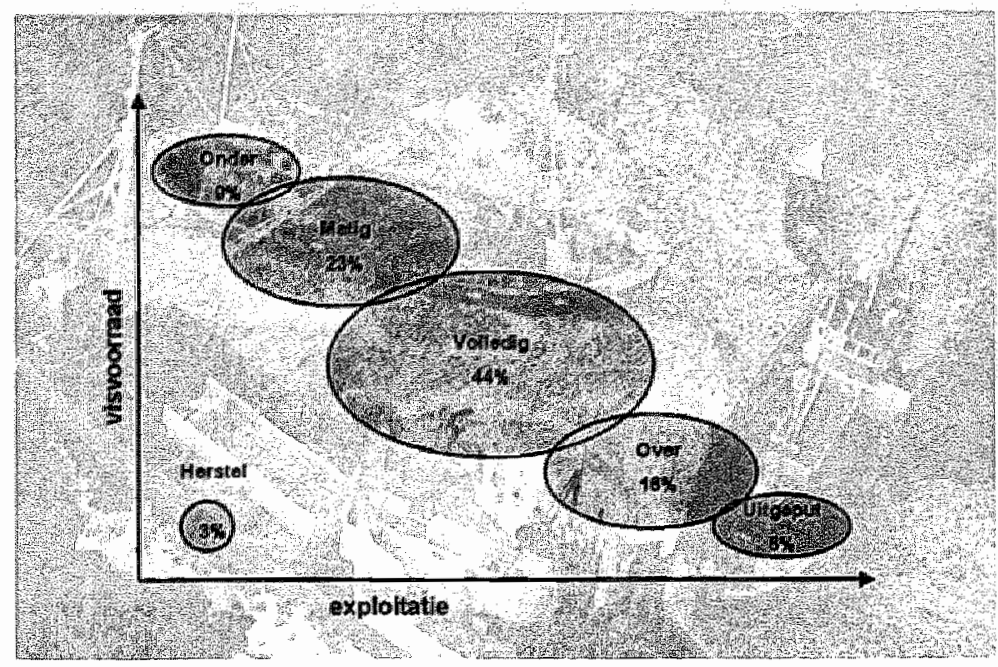

Exploitatie wan de mondiale viswoorraden in 1997 volgens de FAO.

Volgens de FAO [9] is bijna een kwart van de visvoorraden leeggevist of overgeëxploiteerd en wordt bijna de helft in een te hoge mate geëxploiteerd. Bij ongewijzigd beleid zullen de opbrengsten van de visserij omstreeks 2010 met $20 \%$ afnemen. Curieus is echter dat dezelfde organisatie ook beweert dat de visserij met vijf tot tien miljoen ton kan toenemen bij een efficiënter beheer van de voorraden.

Hoewel het voorzorgsprincipe in een groot aantal visserijorganisaties (behalve ICES) wordt toegepast en ondanks het ontwikkelen van duurzaamheidindicatoren [8] en ecolabelling, verkeert de visserij in een crisis. Nog steeds sluit de Europese Gemeenschap kostbare visserijovereenkomsten af met West-Afrikaanse landen, overeenkomsten die in strijd zijn met een duurzaam beheer van deze voorraden [10]. Bovendien heeft de zwaar gesubsidieerde visserij zich ook nag eens verlegd naar de open oceaan, waar niet Arvid Pardo"s notie van "het 
gezamenlijke erfgoed voor de mensheid" geldt, maar het sinds men" senheugenis toegepaste recht van de sterkste en waar illegale visserijpraktijken veelvuldig voorkomen.

Zo wordt er in de diepzee gevist op woorraden in een ecosysteem dat we niet kennen en op vissen, waarvan we de levenscyclus nauwelijks weten. Technologische innovaties als het met satellieten opsporen van veelbelovende vangsten, de sonar en nieuwe netten maar ook het sterk toegenomen motorvermogen van de schepen zelf, hebben geleid tot een "lock-in"-situatie in de terminologie van transitiemanagement. Slechts draconische maatregelen zoals de in mei 2002 aangekondigde reductie van de vloot van de EU met $40 \%[11,12]$ ku nnen leiden tot een meer duurzame visserij.

\section{Visserij lock-in}

De vis wordt duur betaald

( $H$. Heijermans, 1900)

Tijdens de Tweede Wereldoorlog bleven de meeste vissersschepen noodgedwongen in de haven en werd er onbedoeld een grootschialig "wetenschappelijk" experiment uitgevoerd. Door het geheel staken wan de vangst bloeide de visstand op. In 1950 werd er wereldwijd 21 miljoen ton zeevis gevangen. Die oogst aan "fruits de mer" (vis, schelpdieren, garnaal, kreeft, krab, inktvis) groeide spectaculair tot de recordhoogte van 126,2 miljoen ton in 1999 met een waarde van 125 miljard Amerikaanse dollars [9], waarbij de viskweek is meegerekend. De visvangst bedraeg $74 \%$ oftewel 92,9 miljoen ton, terwijl de aquacultuur 33,3 miljoen ton opbracht. In deze data zijn de illegale, niet- 
Dutraam gebruik wan de oceanische ruimte

gerapporteerde en miet-gereguleerde viswangsten - die variêren van $30-300 \%$ van de officieel gerapporteerde vangsten [9] - niet meegenomen.

De vissersvloot groeide in de laatste twintig jaar tweemaal zo snel als de omvang van de mondiale visvangst, damkzij de twintig miljard Amerikaanse dollars $13 \rrbracket$ per jaar, walmee de rijke landen hun industriete visserswloot subsidueren. Tussen 1970 en 1990 verdubbelde het aantal grote vissersschepen van 585,000 tot 1,2 miljoen. We zouden echter niet slechter af $z$ ijn en evenveel vis vangen wanneer we de visserjivloot zouden terugbrengen naar de omvang van de wloot in 19170.

De mondiale whoot is nu zeker meer dan $30 \%$ groter dan nodig. De regionale verschillen zijn echiter groot en bovendien moet onderscheid gemaakt worden tussen de industriële wloten en die voor lokale visvangst. De landen van de Europese Unile hebben $40 \%$ overcapaciteit en de visserij wordt er met minstens 500 miljpen Amerikaanse dollars per jaar gesubsidieerd. Aan het eind van de jaren tachtig waren er in de Canadese prowincie Nova Scotia all viermaal meer trawlers dan nodig om de jaarlijkse quota aan kabeljauw binnen te brengen. Aan de oostikust wan de Verenigde Staten voeren toen 130 trawlers, terwijil een vloot van dertien schepen groot genoeg zou zijin geweest.

In de Verenigde Staten betalen vissers een lagere prijs woor dieselolie en dat betekent een subsidie van minstens 250 miljoen Amerikaanse dollars per jaar. Subsidies voor de (modernisering van) de visserij komen niet alleen in de geindustrialiseerde wereld voor. Maleisie lanceerde met hulp var de Wereldbank een moderniseringsprogramma, waabil tussen 1977 en 1981 de staat alleen voor uitrusting wan de woot dertig miljoen Amerikaanse dollars betaalde. Taiwanese wissers kregen goedkope brandstof, wergelijkbaar met een subsidie van 130 miljoen Amerikaanse dollars in 1991. Ook in de voormalige 
Sovjet Unile werd de visserij instandgehouden met miljoenen Amerikaanse dollars subsidie

Deze gesubsidieerde overcapaciteit, gecombineerd met kraclitige nieuwe technieken (sonar, satellietfoto's, kunstmatige intelligentie) die leder nieum schip efficienter makt in het vinden van wis en het aan land brengen van de vangst, veroorzaakt overbevissing. Technologische unnovaties hebben niet of slechts zeer marginaal bijgedragen aan een duurzaain beheer wan deze woorraad. Maatregelen zijn echter dringend noodzakelujk omdat onze inzichiten in de processen en de voorspelbarheid ervan in de oceanische ruimte exponentieel zullen toenemen met het implementeren van het mondiale informatiesysteem GoO5. Er zal woor gewaakt moeten worden dat dan verkregen informatie wel op een duurzame wijze wordt aangewend. Mocht dit niet het geval zijn, dan zal de oceamische ruimte inderdaad zo letterijk worden leeggevist alls Greenpeace beweert.

Overbevissing is het gevolg van een "pervers beleid" [14] en het gebrek aan internationaal beleid voor het beheer van de oceanische ruimte buiten de EEZ. Tijdens de Wereldtop in Johannesburg zijn een aantal afspraken gemaakt als het elimineren van subsidies die bijdragen aan de illegale visserij en overcapaciteit, om duurzame exploitatie van de visvoorraden dichterbij te brengen. Dit lukt alleen als er een communicatieproces met alle betrokken partijen wordt georganiseerd. De visserijsector met zijn complexe maatschappelijke, economische en ecologische problemen, leent zich daarom uitstekend voor integrated assessment onderzoek, waarmee de communicatie over een transitie naar een duurzaam beheer van deze voorraad op gang kan worden gebracht. 
Duwroam gebrulk wan de oceaniche rumte

\section{Oceaan en klimaat}

Nederland is in hoge mate afhankelijk van wat er in de oceaan gebeurt. Wij leven in een uitzonderllike tijd. Gaan we terug in de geologische tijd, dan zien we dat ijstijden met de gestage afwisseling van glacialen en interglacialen een uitzondering zijn. Het Holoceen, waarin wij leven, is slechts een interglaciaal, waarvan wij de omstandigheden min of meer instinctief tot norm verklaren. Dat is niet juist.

Het variêren of zelfs stilvallen van de mondiale thermohaliene circulatie kan belangrijke klimaatschommelingen teweegbrengen. Uit onderzoek aan ijskernen uit de Groenlandse ijskap is gebleken dat het klimaat boven en rond de Noord-Atlantische Oceaan snel kan verande. ren. Zo kunnen er temperatuursovergangen voorkomen waarbij de gemiddelde temperatuur ruim $5^{\circ} \mathrm{C}$ verandert in enkele decennia [15]. Dit is dus een verandering die zich op de menselijke tijdschaal woltrekt.

Klimaatveranderingen in het Holoceen hebben een grote invloed gehad - en hebben dat uiteraard nog - op de maatschappij, op het komen en gaan van culturen. Onverwachte klimatologische gebeurtenissen leidden tot plotselinge veranderingen in de omgeving van zich vaak min of meer onafhankelijk van elkaar ontwikkelende culturen. Daaraan wist men vaalk niet het hoofd te bieden. Dergelijke veranderingen waren daarom zeer ontwrichtend en leidden vaak tot de ondergang van de heersende maatschappij [16].

Een bekend voorbeeld is de ondergang van de Natufische cultuur in zuidwest Azië. Het gevolg van klimaatwerandering aan het eind van de ijstijd was dat de Natufische jagers en verzamelaars zich in nederzet- 
tingen organiseerden en de vruchtbare gronden in de buurt ervan gingen gebruiken als landbouwgrond. Zo was het mogelijk een aanzienlijk grotere populatie, met allerlei specialisaties in beroepen en maatschappelijke lagen te ontwikkelen en in stand te houden. Deze transitie van jagers en verzamelaars naar landbouwers valt samen met de Jongste Dryas-periode, een plotselinge klimatologische verandering die van 12.900 tot 11.600 duurde.

De stijging van de zeespiegel die het gevolg is van het afsmelten van de ijskappen zorgde eveneens voor ongekende verschijnselen als de door Ryan \& Pitman [17] in hun boek "Noah's Flood" geschetste plotselinge verandering van de Zwarte Zee van een zoetwatermeer in een zoutwaterzee. Het zoute water van de Middellandse Zee vulde ongeveer 7500 jaar geleden via een gigantische, wel tweehonderd meter hoge waterval in de vallei van de huidige Bosporus, in enkele jaren het bekken van de Zwarte Zee en verdrong de aan de rand van het meer levende bevolking. Vergelijkbare situaties moeten zich ook elders op onze planeet hebben voorgedaan, toen de zeespiegel begon aan een stijging van ruim honderd meter naar het huidige niveau.

\section{EI Niño}

In het laar van de Oceaan, 1998, zorgde de El Niño van 1997-1998 voor ongehoorde publiciteit, waartoe met name de meteorologen en niet de oceanografen het initiatief namen. Het fenomeen is ten minste 12.000 jaar [18] en vermoedelijk zo'n 30.000 jaar oud. Het is een grootschalige interactie tussen de oceaan en de atmosfeer die de "Walkercirculatie" wordt genoemd. In gewone jaren is het opperwlaktewater voor de westkust vam Zuid-Amerika koud en door opwelling zeer voedselrijk. El Niño is een verstoring van deze interactie met 
Duthoom gebruik wan de oceanische rumte

belangrijke gevolgen voor het weer op aarde, doordat de passaatwinden zwakker worden, warm water van de West Pacific als een lange long rondom de evenaar stroomt en zich verwolgens naar het noorden en zuiden langs de kusten van Amerika verspreidt. Het koude diepzeewater kan nu niet naar de opperwakte stijgen, de planktonproductie neemt sterk af en de visisen, vogels en zeezoogdieren werhongeren. De Peruaanse visserif-industrie stortte in - mede door de jarenlange overbevissing - na de El Niño van 1972-1973.

Het warmere water veroorzaakt een grotere verdamping aan de Aimerikalanse westkust. Dat leidt tot enorme stortbuien aan de kusten, bijvorbeeld in Peru waar normaal een bar woestijnklimaat heerst. Er ontstalan overstromingen en aardverschuivingen die vele miljarden euro's schade veroorzaken en de bewoners van deze gebieden bedreigen. De effecten van een El Niño zijn ook war"neembaar in Azië en Australie, op het Antarctisch Schiereiland en de Atlantische Oceaan. Herdoor is het een mondiaal klimaatsfenomeen.

De oudste beschreven krachtige El Niño stamt uit 1525 toen de Spaanse conquistadores onder leiding van de meedogenloze Francisco Pizarri de Incahoofd. stad Cuzco in Peru veraverde [19]. Dankzij de zware regenval vonden zij in de aan de kust grenzende woestijn voldoende voedsel voor zichzelf en huin paarden. Waren zij een jaar eerder of later naar Cuzco opgetrokken, dan hadden zij] de tocht dloor de onherbergzame woestijn ongetwiffeld niet overleefd.

De totale directe economische schade van de laatste en hevigste El Niño vam de twintigste eeuw wordt geschat op 34 miljard Amerikaanse dollars [20]. De sociale gevolgen zijn echter veel omvattender. Zo ondervonden meer dan 110 miljoen mensen op de eeri of andere manthier effecten wan het verschinsel, waren ar zes miljoen milleuvluchtelingen en stierven er 24.000 mensen door zware 
stormen Het zal duideli $\mathrm{k}$ zjn dat betrouwbare voorspellingen van een E Niho vangroot social, economisch en ecologisch belang zin.

\section{Mens en oceaan}

De kapitein van het Duitse onderzoekschip Polarsterm vertelde me eens. bij het zien van een vieze ${ }_{n}$ bruine inversielaag die Engeland met het vasteland verbond, dat hij Kaapstad op een afstand van 150 kilometer kon ruiken. Deze opmerking illustreert op treffende wijze het feit dat, hoewell de effecten van het menselijk handelen overal in de oceanische ruimte warneembaar zijn, ze aan intensiteit toenemen als we de kust naderen. Van oudsher is de kust - de interface tussen de oceanische ruimte en de continenten - een plaats, waar vele menselijke activiteiten samenkomen.

In de afgelopen decennia zijn deze activiteiten enorm toegenomen. Het kustgebied heeft in hoge te mate te leiden onder een reeks slecht gereguleerde en geplande activiteiten als de explosieve bevolkingsgroei en urbanisatie, het toenemende toerisme, de industrialisatie en de ontwikkeling van aquacultuur, de aanleg van havens en de erbij behorende infrastructuur en stormwloedkerende maatregelen. De toenemende menselijke activiteit valt vooral op in ontwikkelingslanden, waar de snelle bevolkingsgroei samengaat met hardnekkige armoede. Meer dan $70 \%$ van de megastedlen ligt in kustgebieden [21]. Megasteden hebben ook een grote invloed op hun omgeving, door hun ecologische voetafdruk [22], door hun grond- en watergebruik en luchtvervuiling. Zo is de ecologische voetafdruk van Londen ruim 125 maal groter dan de oppervlakte van de stad. 
Durzaom gebruik van de aceanische rumte

De kust is een gebied vol paradoxen. Aan de ene kant is er ruimte nodig voor de steeds toenemende menselijke activiteit; aan de andere kant is die ruimte door zijn reinigend vermogen ook nodig om die activiteiten in stand te houden. In het kustgebied - dat in een wat breder opgevatte definitie bijna $20 \%$ van het aardopperwlak beslaat - leeft meer dan de helft van de wereldbevolking [23]. Over 25 jaar zal $75 \%$ van de wereldbevolking in dit gebied wonen. Dat is evenveel als de totale wereldbevolking in 1997 .

Kustecosystemen zijn zeer productief, zij leveren $90 \%$ van de mondiale visserij en $25 \%$ van mondiale biologische productiviteit. Bovendien zijn ze verantwoordelijk voor het schoonmaken van een gestaag groeiende stroom afvalproducten als kunstmest, oestrogene stoffen en rioolwater van menselijke activiteiten op land.

Er zijn een groot aantal gebruikersfuncties van de kust [24] als: veiligheid milieu, watermanagement, energie, mijnbouw, bouwlocaties, recreatie, toerisme, infrastructuur, transport en telecommunicatie. Een geïntegreerde aanpak van de complexe problemen in het kustgebied ligt dan ook zeer voor de hand en komt tot uiting in het geïntegreerde kustbeheer. Toch missen hierin vaak de sociaal-culturele aspecten. Binnen het ICIS worden dergelijke problemen met het SCENE-model wel vanuit de sociale, ecologische en economische dimensies bestudeerd. Bovendien wordt de waarde van het kustgebied gewoonlijk slechts afgewogen in termen van de waarde van de voorraden, die worden geëxploiteerd, of het nu gaat om olie en gas, grind, zand of vis. Deze warden vallen echter in het niet bij de diensten - een veelvoud van het mondiale BNP - die geleverd worden in de vorm van natuurlijke bescherming tegen overstromingen, broedkamers voor vissen en het 
reinigen van afvalwater. Wij plaatsen die diensten woor het gemak buiten de markteconomie. Hierdoor worden besluiten genomen op verkeerde gronden en dus met verkeerde gevolgen. Dat moet veranderen.

De kustlijn wordt gewoonlijk beschouwd als de grens tussen de oceanische ruimte en het land. Deze notie weerspiegelt het landgerichte denken van de mens. Op zichzelf is dit niet verwonderlijk: wij zijn nu eenmaal landbewoners. Vanuit oceanisch perspectief is het aangeven van de grenzen van de invloed van de oceaan echter zeer complex. Als onderdeel van het Systeem Aarde is er via de hydrologische kringloop een directe band met de neerslag op de continenten. Het waterbeheer op macroniveau is direct gerelateerd aan processen die zich in de oceaan afspelen. Zo wordt de regenval in Eritrea niet bepaald door processen in de Indische Oceaan, maar door de Noord-Atlantische oscillatie in en boven de Atlantische Oceaan, terwijl de regenval in Namibië onder invloed van het El-Niño-systeem afhankelijk is van de Stille en indische Oceaan. De regenval in Angola wordt echter weer bepaald door de Atlantische Oceaan.

Driehoeksmodel

Het uitgangspunt van het SCENE- of driehoeksmodel is dat binnen een complex maatschappelijk probleem een aantal dimensies zijn te onderscheiden die zijn the relateren aan bijvoorbeeld duurzame ontwikkeling [25]. Er bestaan vele definities wan duurzame ontwikkeling. Alle hebben echter gemeen dat ze betrekking hebben op de samenhang en interactie tussen ecologische, economische en sociaal-culturele ontwikkelingen. In ons denkmodel worden deze dimensies weergegeven als kapitaalvormen, die zijn opgebouwd uit voarraden. 


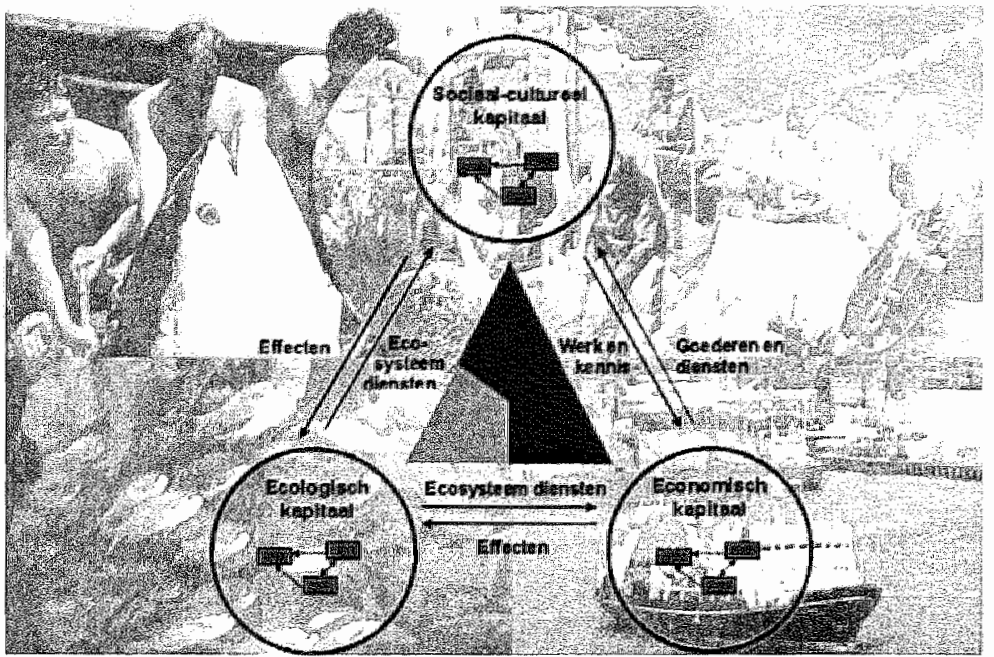

Voorbeelden van voorraden in de oceanische ruimte zijn de bevolkingssamenstelling aan de kust, velligheid, recreatie, inkomen (sociaal-cultureel kapitala (), thevende hulpbronnen, wetlands, koraalriffen, regenwater, vervuiling, mariene blodiversiteit (ecologisch kapitaal), olle en gas, mariene mineralen, transport, energie, toerisme, visserij en $\mathrm{CO}_{2}$-opslag (economisch kapitaal).

De relaties tussen de verschillende voorraden binnen een kapitaalsworm worden intrastromen genoend en die tussen de verschillende kapitaalsvormen interstromen. Zo is de bevolkingsgroei in kustgebiedlen een woorbeeld van een înterstroom binnen het sociaal-cultureel kapital door het effect ervan op de veiligheid en werkgelegenheid, terwijl het door het ruimtegebruik een intrastrom tussen het sociaal-cultureel kapitaal en het ecologisch kapitaal kam veroorzaken. De samenstelling van de voorraden verandert hierdoor in kwaliteit en kwantiteit. We kunnen dus stellen dat er door menselijke activiteit als de visserij, mijnbouw en scheepvart een uitwisseling plaatswindt tussen de verschillende kapitalswormen en de voorraden daarin. 
Het oppervlak van de driehoek representeent de omvang van het totale ongevingskapitaal. In de loop van de tijd kunnen er zich de volgende drie ontwikke. lingen [26] voordoen:

- De omvang van de driehoek neemt af wat inhoudt dat de omvang van het totale kapitaal afneemt (verzwakking)

- De onvang van de driehoek blijtt gelijk, maar de grootte van de deelgebleden verandert, wat betekent dat er uitwisseling tussen de verschillende kapitaalsvormen plaatsvindt (substitutie).

- De omvang van de driehoek neemt toe, wat betekent dat het totale kapltaal toeneemt (versterking).

Met behulp van dit model kan dus op eenvoudige wijze zichtbaar worden gemaakt:

- Wat de ontwikkeling is in de omgeving van het totale omgevingskapitaal door de verandering in de grootte van het oppervlak van de driehoek.

- Wat de ontwikkeling is in de verdeling tussen de werschillende kapitaalsvormen door veranderingen in de oppervlakteverdeling binnen de driehoek.

Het driehoeksmodel leent zich bij uitstek voor het op een gestructureerde wijze zichtbaar maken van de vele relaties die een rol spelen in complexe maatschappelijke problemen, als bijvoorbeeld de gevolgen van klimaatwerandering en van het duurzame gebruik van de oceanische ruimte:

Vervuiling, eutrofiëring en niet-inheemse soorten

De vervuiling van de oceanische ruimte staat de laatste jaren wat minder in de publieke belangstelling door de aandacht voor andere bedreigingen, zoals overbevissing en habitatvernietiging. De schade door vervuiling is echter alleen maar toegenomen. Door de snelle bevol- 
kingsgroel en de urbanisatie verdrinken vele kustgebieden nu bil wijze van spreken in het rioolwater. Hierdoor worden vis- en recreatiegebieden vernietigd, met als gevolg grote economische schade. Het eten van besmette "fruits de mer" of het baden in zee leidt veelvuldig tot maagen darmziekten zoals cholera, tyfus en hepatitis.

De microbiologische besmetting van de zee is geen lokaal verschijnsel. Volgens de WHO wordt één op de twintig badgasten ziek door te ba* den in door de overheid goedgekeurd zeewater. Dit veroorzaakt op mondiale schaal 250 miljoen gevallen van gastro-enteritis en heeft daarmee een impact vergellijkbaar met die van difterie en lepra. De maatschappelijke kosten zijn circa 1,6 miljard Amerikaanse dollars per jaar. Jaarlijks worden er ongeveer acht milljard maaltijden met schaaldieren gegeten. Het eten van door rioolwater vervuildie ongekookte schaaldieren leidt tot 2,5 miljoen gevallen van hepatitis met een gezamenlijke schade van tien miljard Amerikaanse dollars per jaar [13].

Eutrofiëring komt vooral in kuistgebieden en de EEZ voor en uit zïch onder andere in een groeiend aantal al dan niet toxische algenbloeien. Langdurige toename van de planktongroei kan leiden tot dramatische veranderingen in het ecosysteem. Dode zones in de Golf van Mexico zijn het gevolg van het gebruik van kunstmest in het stroomgebied van de Mississippi, die daarmee ook functioneert als een turbotoilet. Eutrofiëring kan ook leiden tot een snelle groei van zeegrassen waardoor de rifgroei kan verstikken.

Hoewel er wel eerder grote invasies van niet-inheemse soorten zijn geweest - door bijvoorbeeld de aanleg van het Suez Kanaal - verplaatst de mens nu niet-inheemse soorten op ongekende schaal. Elke 
dag worden er circa 3000 "allien species" in het ballastwater van schepen over de wereld vervoerd. ze komen samen met het noodzakelijke voedsel aan boord en worden enige dagen of weken later weer geloosd. Een bekend voorbeeld is de introductie van de Amerikaanse ribkwal Mnemiopsis leidyi in de Zwarte Zee, waar zich een sciencefictionachtig scenario ontwikkelde, omdat deze hermafrodiete dieren zichzelf bevruchten. Uiteindelijk leidde dit in 1988 tot het instorten van de planktonpopulatie dat het voedsel van de kwal vormt. Daardoor was er ook geen voedsel meer voor de vissen, terwijl dle ribkwallen zich ook nog eens te goed deden aan de eieren en larven van de vissen. In een kleine tien jaar bedroeg de economische schade ten minste driehonderd miljoen Amerikaanse dollars en waren de sociale consequenties niet te overzien. Niet-inheemse soorten zijn tijdbommen, omdat het waak enige decennia duurt voordat de nieuwe populaties voldoende groot zijn om te kunnen worden waargenomen.

Oceanische ruimte en menselijke activiteit bij JCIS

De relatie tussen de oceanische ruimte en de menselijke activiteit is innig. Toch is in het begin van de $21^{\text {ste }}$ eeuw nog steeds het grootste deel van de oceanische ruimte onbekend en niet verkend: $95 \%$ van de zeebodem is niet in kaart gebracht. De verkenning van de waterkolom, het grootste bioom op aarde, staat nog in de kinderschoenen [2]. Hiervoor worden nieuwe instrumenten (ROV's, intelligente floats en gliders, autosub) en technieken (akoestische) ontwikkeld. Er zal zich de komende decennia mede door het operationaliseren van het mariene informatiesysteem GOOS en nieuwe wetenschappelijke inzichten, een revolutie in het verkennen en duurzaam exploiteren en beheren van de oceanische ruimte gaan afspelen. Integrated assessment kan hierbij 
Duurzam gebruklk van de oceanir he ruimte

beleidsmatig en wetenschappelijk een belangrijke, vernieuwende rol spelen. Mijn werk binnen het ICIS zal zich hierop in de komende jaren richten. Het onderzoek en onderwijs betreffen onderwerpen als oceaanbeleild, duurzame ontwikkeling wan de EEZ en menselijke activiteit in met name de kustzone.

\section{Nieuw oceaanbeleid nodig}

Eeuwenlang bestond er een vrij directe relatie tussen de belangen van grootmachten en de wijze waarop de rechten van het gebruik van de zee zijn geformuleerd. De Romeinen waren van mening dat men de zee, evenals het land, kon bezitten en introduceerden het begrip Mare Nostrum. Deze mening heeft lange tijd opgang gedaan en was in de vijftiende en zestiende eeuw de gangbare opvatting onder de toenmalige zeemachten. Zo introduceerde Portugal in het begin van de zestiende eeuw het begrip Mare Clausum voor de eigen zeevaarders en kooplieden.

De huidige notie van "de vrije zee" gaat terug naar het begin van de zeventiende eeuw, toen de VOC de twintigjarige jurist Hugo de Groot aantrok om de inbeslagname van een met schatten beladen Portugees galjoen in de Straat van Malakka te verdedigen. De Groot verdedigde deze visie in zijn korte verhandeling Mare Liberum (1609), waarin hij pleitte voor de vrije handel en een voor ieders handel toegankelijke zee. Deze visie was tegen het einde van de zeventiende ceuw algemeen geaccepteerd. De zienswijze van De Groot heeft een belangrijke bijdrage geleverd aan de internationale handel, zeevart en investeringen en in de meer recente tijd tot samenwerking op gebieden als toerisme, wetenschappelijk onderzoek en veiligheid op zee. De andere kant van 
de medaille is echter dat het beginsel van de "vrije zee" ook de weg heeft vrijgemaakt voor machtspolitiek, militair machtsvertoon, kolonialisme en meer recent voor het straffeloos lozen van afval em voor overbevissing [27].

De oceanische ruimte - de eeuwige zee, Mare sit Aeternum - leent zich door de afwezigheid van een "eigenaar" en het openbare karakter ervan in hoge mate voor een participerende beheersvorm, waarin stakeholders buiten de overheid een rol spelen. Dit betekent dan wel dat de samenleving beter geïnformeerd dient te zijn over wat er in de oceanische ruimte gebeurt en wat het belang van dit alles is. Daarom pleit ik in samenwerking met het International Ocean Institute op Malta voor de oprichting van een onafhankelijk, gespecialiseerd Oceaan Persbureau. Het is ook duidelijk dat het Zeerecht niet af is, zolang er (in de geest van het Verdrag) geen bindende afspraken worden gemaakt over andere voorraden dan de mangaanknollen. Integrated assessment is een prachtig instrument om de complexe problematiek van het beheer en de duurzame ontwikkeling van de open oceanische ruimte in kaart te brengen en te adviseren over mogelijke oplossingen. We zullen van ons laten horen!

\section{Exclusieve Economische Zone}

Een van de meest zichtbare gevolgen van het nieuwe Zeerecht dat in 1994 van kracht werd, is de instelling van de EEZ van 370 kilometer. Hierdoor komt een zeegebied even groot als het landoppervlak van de continenten onder nationale jurisdictie. Het uit water bestaande oppervlak van landen is in vele gevallen enorm toegenomen. Zo heeft de oceanische ruimte van de Nederlandse Antillen een oppervlakte van 
$120.000 \mathrm{~km}^{2}$ (bijna viermaal het landoppervlak wan Nederland), terwijl het landioppervlak $960 \mathrm{~km}^{2}$ is.

\begin{tabular}{|l|l|l|l|}
\hline Land & $\begin{array}{l}\text { Oppervlakte EEZ } \\
\text { in } \mathrm{km}^{*}\end{array}$ & $\begin{array}{l}\text { Oppervlakte land } \\
\text { in } \mathrm{km}^{2}\end{array}$ & $\begin{array}{l}\text { Aantal inwoners } \\
(j u l i ~ 2001)\end{array}$ \\
\hline Frankrijk & 9.956 .400 & 547.030 & 59.982 .295 \\
\hline USA & 7.621 .300 & 9.629 .091 & 278.058 .881 \\
\hline Australie & 7.008 .300 & 7.686 .850 & 19.357 .594 \\
\hline Indonesie & 4.410 .000 & 1.919 .440 & 228.437 .870 \\
\hline Nieuw-Zeeland & 4.83 .4 .400 & 268.680 & 3.864 .129 \\
\hline Canada & 4.699 .000 & 9.976 .1 .40 & 31.592 .805 \\
\hline Rusiland & 4.491 .500 & 17.075 .200 & 145.470 .197 \\
\hline
\end{tabular}

De zeven grootste oceaanstaten ter wereld.

In het Zeerechtverdrag hebben de kuststaten het recht het gebruik van de EEZ te reguleren via ontginnings- en vangstlicenties voor delfstoffen en de mariene fauna en flora. Andere licenties reguleren het gebruik van havens en stranden. Om de voorraden in de EEZ echter duurzaam te exploiteren moet er een verandering in het denken en handelen plaatsvinden, zodat de milieukosten wel worden meegerekend via gebruiksgelden, belastingen en royalty's. Er is dus een transitie nodig van een niet-duurzaam gebruik van de mariene voorraden naar een duurzaam beheer. Het is duidelijk dat de geindustrialiseerde landen hier een bijzondere verantwoordelijkheid hebben, omdat ze over de nodige kennis, kunde en kapitaal beschikken.

EEZ-beleid vereist structuren, die robuust en flexibel genoeg zijn om te kunnen inspelen op plotselinge veranderingen en nieuwe inzichten. 
Een van de grote obstakels bij het formuleren van een dergelijk geïntegreerd beleild is de fragmentatie van de betrokken organisaties. Op mondiaal niveau bestaan er al een reeks van VN-organisaties (FAO, UNEP, UNDP, IOC, WMO, WTO) die zich op de een of andere manier met een aspect van het oceaanbeleid bezighouden. Op regionaal (Noordzee) en nationaal niveau is de situatie dikwijls nog complexer. Neem Nederland, waar bijna alle ministeries wel een bevoegdheid hebben die verband houdt met de oceaan. Het Nederlandse beleid is, wellicht vanwege onze veel geroemde strijd tegen de zee, in hoge mate landgericht met een gebrekkige coördinatie en een gebrek aan visie. Zelden wordt er rekening gehouden met het geîntegreerde karakter van oceaanbeheer. Zo stimuleert het ene ministerie de EEZ als een groene exportmarkt, sluit het andere samenwerkingsovereenkomsten af waarin het waterbeheer bij de kust ophoudt en heeft weer een ander ministerie geen enkel oog voor kennisoverdracht naar ontwikkelingslanden in relatie met oceanografisch onderzoek.

Hoe dan well? Tot nu toe zijn daar twee antwoorden op te geven. In enkele gevallen is er op hoog niveau - bijwoorbeeld binnen het kabinet van een president - een speciale commissie die een en ander coördineert. Of men richt, zoals in Indonesië en Zuid-Korea, een speciaal ministerie op. Van oudsher speelt de zee een grote rol in de Indonesische cultuur. Indonesië, het vierde oceanische rijk ter wereld, bestaat uit maar liefst 17.000 bergtoppen, die we eilanden noemen. Hierop leeft, woont en werkt een bevolking van een kleine 230 miljoen mensen. Indonesie is een voorbeeld van een oceaanstaat in transitie waarbij de exploitatie van de voorraden in de zee en de zeebodem een belangrijke economische factor is evenals de exploitatie van de schoonheid van de kusten. 
Binnen het ICIS zijn we dan ook van plan om een integrated assessment van de EEZ van Indonesië uit te voeren, waarbij ook zal worden ingezoomd op de problematiek van grote bevolkingsconcentraties. Dit is slechts een van de vele onderwerpen waarbij het onderzoek van het ICIS voor nieuwe inzichten kan zorgen. Andere onderwerpen van onderzoek binnen het "duurzaam gebruik van de oceanische ruimte" betreffen thet kapitaal van de EEZ met zijn vele voorraden in termen van vis, aquacultuur, gashydraten, olie en gas, biodiversiteit, genetische informatie, farmaceutische producten en toerisme met cruiseschepen.

\section{Nationaal}

Kustgebieden en delta's zijn evenals koraaleillanden, ook de plaatsen, waar de in het IPPC 2001 rapport [28] voorspelde effecten van klimaatverandering met een verwachte zeespiegelstijging van gemiddeld 48 centimeter tegen het jaar 2100 , het meest zichtbaar zullen zijn. In Nederland vormen de menselijke activiteit in het gebied tussen Rotterdam, Den Haag, Amsterdam en Utrecht met het Groene Hart en de mainports Rotterdam en Schiphol, de motor van onze economische ontwikkeling. Deze menselijke activiteit vindt plaats in een gebied met zeer karakteristieke eigenschappen. In een delta, warin bodemdaling door de rebound van de laatste ijstijd, zeespiegelstijging en een veranderende afvoer van rivierwater belangrijke fysieke elementen zijn.

De mogeifjke effecten van klimaatveranderingen en de menselijke activiteit in deze policentrische Delta Metropool vereisen een geïntegreerde visle op een duurzame ontwikkeling van dit gebied. Integrated 
assessment, een interdisciplinair en participatief proces om van belangzijnde kenniselementen op een creatieve wijze te combineren woor de ondersteuning van de besluitvorming [29], is in het duurzame beheer van de kust, de EEZ en de oceaan, een nieuw en innovatief beleidsinstrument, dat nog volop in ontwikkeling is. Om het wetenschappelijk onderzoek op dit terrein en toegespitst op het duurzame gebruik en beheer van de EEZ te stimuleren, heeft het ICIS het initiatief genomen tot een multidisciplinair, thematisch samenwerkingsverband met de Universiteiten van Delft, Utrecht en Wageningen en de Vrije Universiteit in Amsterdam.

Het ICIS bestaat bijna vijf jaar. Het is een jong en zeer dynamisch instituut als onderdeel van een jonge en dynamische universiteit, met oog voor de maatschappij. Ons onderzoeksinstituut heeft een uitermate interessante "gereedschapskist" ontwikkeld die zeer bruikbaar is om duurzame ontwikkeling van de EEZ en de kustzone in goede banen te leiden. ICIS BV vermarkt de ideeën van de onderzoekers en brengt ze soms enige realiteitszin bij. Het is juist deze combinatie van onderzoek en een open oog voor de toepassing ervan op een nieuwe markt - de $E E Z$, de groene exportmarkt voor BV Nederland - die het werken bij het ICIS voor mij aantrekkelijk maken. Daarnaast biedt het komende bache lor-en mastersprogramma binnen het samenwerkingsverband met de Universiteit wan Diepenbeek een prachtige en uitdagende kans onze en mijn ideeën over te dragen aan een jongere, enthousiaste generatie. Ik hoop $u$ daarover in mijn afscheidscollege in 2012 te kunnen informeren. 


\section{Dankwoord}

Aam het eind van deze rede, mijnheer de Rector Magnificus, dames en heren, will ik een aantal mensen bedanken die hebben bijgedragen aan de totstandkoming van mijn benoeming bij het ICIS van deze universiteit. Allereerst wil ik het College van Bestuur en de leden van de Faculteit van de Algemene Wetenschappen en de Nederlandse Organisatie voor Wetenschappelijk Onderzoek bedanken voor het in mij gestelde vertrouwen en de mij geboden mogelijkheden.

Mijn dank gaat ook uit maar de zeergeleerde heer Van Spiegel, voormalig directeur-generaal van het ministerie van Wetenschapsbeleid, die mij een ongekende vrijheid gaf om het Nederlandse oceanografische onderzoek in de jaren tachtig en negentig gestalte te geven. Op het terrein van de oceanografie werd Nederland het vierde grote land in Europa $a_{\text {in }}$ plaats van het grootste kleine land. Beste Egbert, zonder het te weten stond je aan de wieg van deze benoeming. Ik ben je erkentelijk voor het in mij gestelde vertrouwen. Je was een fijne leermeester.

Hooggeleerde Van der Laan, beste Harry. Nooit zal ik ons eerste onderhoud, in Wijk bij Duurstede, vergeten. Je vertelde me dat ik - volgens NWO - een sterke persoonlijkheid had, die onze samenwerking in de weg kon staan. ledereen ging hierbij voorbij aan de affiniteit tussen rationele Groningers en hun gedeelde wens iets moois tot stand te brengen. De Nederlandse deelname aan het Europese ijsboorprogramma EPICA, waartoe wij op goede gronden NWO wisten te verleiden, is hiervan een mooi woorbeeld. De samenwerking met jou was een verademing in mijn carrière. 
Hooggeleerde Rotmans, beste Jan. Mijin eerste kennïsmaking met jou toen nog aan de Kapoenstraat, maakte al snel duidelijk dat er een syn. ergie is tussen ICIS en mijn werk in de oceanografie tot dan toe. Tegen de tijd dat ik formeel bij het ICIS werd aangesteld, was het instituut in omvang verdubbeld. Dat typeert je en spreekt mij aan. Binnen vijf jaar heb je een dynamisch en nationaal en internationaal gerenommeerd instituut van de grond getilld. Het is een genoegen om in de Maastrichtse onderzoeksomgeving mee te kunnen bouwen aan ICIS. Ik ben je erkentelijk voor je inspanningen om mijn benoeming gestalte te geven.

Weledele Wiese, beste Kees. Je was de eerste journalist die mij een interview afinam toen ik in 1978 bij Bert Boekschoten, de hooggeleerde heer Boekschoten, promoveerde. In die tijd was ik, volgens jou, een typische wetenschapper. Je was dan ook zeer verbaasd imij daarna als "science manager" tegen te komen. Samen met natuurfotograaf Fred Hoogervorst hebben we vele initiatieven genomen. Ik ben jullie erkentelijk voor jullie vriendschap.

Mijn dank gaat ook uit naar alle collega's van het ICIS en NWO, die zorgen voor een dynamische en inspirerende werkomgeving.

Het thuisfront ben ik de meeste dank verschuldigd. Overigens niet omdat ze mij de ruimte gaven om weer eens een publicatie of boek te schrijven of weer eens een door vellen als wild plan beschouwde activiteit gestalte te geven. Janneke, Evianne, Bernaart en Monique, mijn dankbaarheid ten opzichte van jullie is geen onderwerp van een rede, dat blijft hier dus verder ongezegd. 
Dutraom gebruik van de aceanische ruimte

$\cup$ allen hier aanwezig will ik tot slot hartelijk danken dat $u$ de moeite genomen heeft om naar Maastricht te komen om bij mijn rede aanwezig te zijn. Immers in de praktijk blijkt de afstand tussen bijvoorbeeld Groningen of Lutjebroek of Den Haag en Maastricht groter te zijn dan andersom.

I d dank u voor uw aandacht.

Ik heb gezegd. 


\section{Referenties}

1. Kremer, M.,1993. Population Growth and Technical Change, One Million B.C. to 1990. Quarterly Journal of Economics, 108, 3: 681716.

2. MoNutt, M., 2002. Ocean exploration, Oceanography, 15, 1: 112121.

3. Levathes, $L, 1996$. When China ruled the seas. Oxford University Press.

4. Villiers, A, 1962. Het avontuur van de zee. National Geographic Society: $1-434$.

5. Rotmans, J., Kemp.R., van Asselt, M.B.A., Geels, F., Verbong, $G_{\text {. }}$ Molendijk, $K_{w}$, 2000. Transities \& Transitiemamagement: de casus van een emissiearme energievoorziening, International Centre for Integrative Studies (ICIS), Maastricht: 1-123.

6. Akveld, L \& E.M. Jacobs. The colourful world of the VOC. National anniversary book VOC 1602-2002. Thoth Publishers, Bussum: 1190.

7. Vandermissen, H. 1983. Nederlanders en de zee. Unieboek, Bussum: 1-184.

8. FAO, 2000. State of world fisheries and aquaculture (SOFIA), deel 1 en $2: 1-84$.

9. FAO, 2002. Fisheries Trends. (www.fao.org/fi/trends/worldprodg9e.asp)

10. Kaczynski, V.M. \& D.L. Fluharty, 2002. European policies in West Africa: who benefits from fisheries agreements? Marine Policy, 26, 2: 75-95.

11. Kirwin, J., 2002. Something stinks. Time, June 20:34. 
12. Mackenzie, D., 2002. Fish out the politicians. New Scientist, 8 June 2002: 4 .

13. CESAMP rapport, 2001. A sea of trouble, UNEP: 1-35.

14. Jackson, J.B.C., M.X. Kirby, et al, 2001. Historical overfishing and the recent collapse of coastal ecosystems, Science, 293, 5530: 629637.

15. Alley, R.B., 2000. The two-mile time machine: ice cores, abrupt climate change, and our future. Princeton University Press, Princeton, New Jersey, USA: 1-220.

16. Weiss, $H_{1}, 2001$. What drives societal collapse? Science, 291: 206207.

17. Ryan, W. \& W. Pitman, 1998. Noah's flood. Touchstone: 1-319.

18. Rittenour, T.M., Brigham-Grette, J. \& Mann, M.E., 2000. El Niño-like climate teleconnections in New England during the Late Pleistocene. Science, 288, 1039-1042.

19. Enfield, D.B., 1998. Is El Niño becoming more common? Oceanog. raphy, November: $23-27$.

20. WMO, 1999. The 1997-1998 El Niño event: a scientific and technical; retrospective, Geneva.

21. IOC, 1999. IOC-SOA International workshop on coastal megacities - challenges of growing urbanisation of the world's coastal areas. IOC, workshop report no. 166.

22. WWF, 2002. Living planet report 2002. Geneva: 1-32.

23. 10C, 2002. Towards the 2002 World Summit on sustainable development Johannesburg. Ensuring the sustainable development of oceans and coasts. A call to action. Paris: 1-38.

24. Waterman, R.E., 1999-2000. Sustainable coastal zone development in harmony with the natural environment. 1-78. 
25. Rotmans, I., J. Grosikurth, M. van Asselt \& D. Loorbach, 2001. Duurzame ontwikkeling, van concept naar uitvoering. ICIS: 1-59.

26. Van Asselt, M.B.A., N. Rijkens-Klomp \& K. Molendijk, 2000. Werken met het denkmodel. ICIS working paper 100-D002: 1-89.

27. Borgese, E. Mann, 1998. The oceanic cycle, United Nations University Press, Tokyo: 1-240.

28. $\triangle P C C, 2001$. Climate Change 2001: Synthesis report. Cambridge University Press: 1-395. 